\title{
Application of belt conveyors and determination of the main parameters of mobile complexes for the transportation of overburden rocks of the Angren coal mine
}

\author{
Annakulov Tulkin ${ }^{1}$, Mamatov Dostonbek ${ }^{2}$, Eshonqulov Kamoljon ${ }^{3}$ \\ 1,2,3 Tashkent state technical university named after Islam Karimov, University street 2, Tashkent, 100095
}

Uzbekistana.tulkin1275@yandex.ru

\begin{abstract}
This article provides information on the use of cyclicalflow technologies at the Angrencoal mine of the Republic of Uzbekistan. The method for determining the development time and productivity of the complex during the development of overburden benches in the Angren coal mine is presented. The technological scheme of the development of benches by longitudinal entry of a mobile excavator-crushing complex with a lateral location of the bottoming conveyor and the presence of a mobile inter-step reloader is considered.
\end{abstract}

Key words: cyclic-flow technology, mobile complexes, belt conveyor, excavator-crushing complex, complex productivity.

\section{INTRODUCTION}

The Angren coal mine is located on the territory of the Tashkent region of the Republic of Uzbekistan and is located in the valley of the Akhangaranriver between the Chatkal and Kuramin ranges. The field stretches from southwest to northeast for $9 \mathrm{~km}$ and from southeast to northwest for $15 \mathrm{~km}$. The total area of the deposit is about $70 \mathrm{~km}^{2}$.

The Angren open-cast mine is a unique kaolin - coal deposit. Overburden rocks (associated minerals) lie at the top of the coal seam: secondary gray kaolins, secondary variegated kaolins, calcareous sandstones, siltstones, quartz-mica sandstones, dolomitized and pure limestones, marls, loams, pebbles, loess. Mining and geologic conditions of the bedding of the Angren coal mine field predetermined the use of the transport system of development in the section with the movement of overburden into external and internal dumps by means of railway, road and conveyor transport.

The heights of the mining and overburden benches were up to $15 \mathrm{~m}$. The width of the working platforms varied within 35-100 m. As a result of the impact of landslide processes in the southwestern, western and northwestern sections, the width of the working platforms of coal and kaolin benches was from 50 to 60 meters. The direction of the work front is from south to west. Mining operations at the "Upper" complex are carried out selectively using ЭКГ-4y excavators with loading onto road transport. At the same time, the ash content of coal reaches 30-35\%. Mining operations at the Angren coal mine open being carried out at the Upper and Powerful complexes $61 \%$ of the mined coal falls on the "Powerful" complex, 39\% - on the "Upper" complex. At the "Powerful" complex, mining benches are worked out by excavators with loading on conveyor and road transport, where excavators ЭКГ-5A and ЭКГ-4yoperate $[1,2,3]$.

In accordance with the established assignment for the Angren coal mine Open-Pit Branch for coal production in the amount of 3,200.0 thousand. tons, taking into account the implementation of the Government Program for the provision of solid fuel to the regions of the Republic of Uzbekistan, the following main types of stripping operations are envisaged [3]:

stripping works, total - 29500 thousand $\mathrm{m}^{3}$,

including, by type of transport:

railway - 9,000 thousand $\mathrm{m}^{3}$.

automobile transportation - 12,000 thousand $\mathrm{m}^{3}$.

With out transportation $-2,500$ thousand $\mathrm{m}^{3}$.

Cyclic-flow technology - 6,000 thousand $\mathrm{m}^{3}$.

In march of the 2015 year, it was received andinstalled.The excavator type of ЭКГ-15M was put into operation. in addition, in 2014 year 4 conveyors of the central heating center of the coal direction and the loading and sorting point

(LSP) "Dzhigiristan" were put into operation.

At the Angren coal mine, a technological scheme for organizing mining operations is used in the development of overburden [2,4,5]: with the installation of a mobile conveyor-reloader or inter-step conveyor-reloader between the mobile crusher and the face conveyor (Fig. 1). The rock is loaded by the excavator into the crushers through the feed hopper. Rock from the crushing plant is transferred to a mobile transfer conveyor and then to the face conveyor. The use of a mobile conveyor-reloader allows to reduce the frequent movement of the face conveyor and place them at a great distance from the face; 


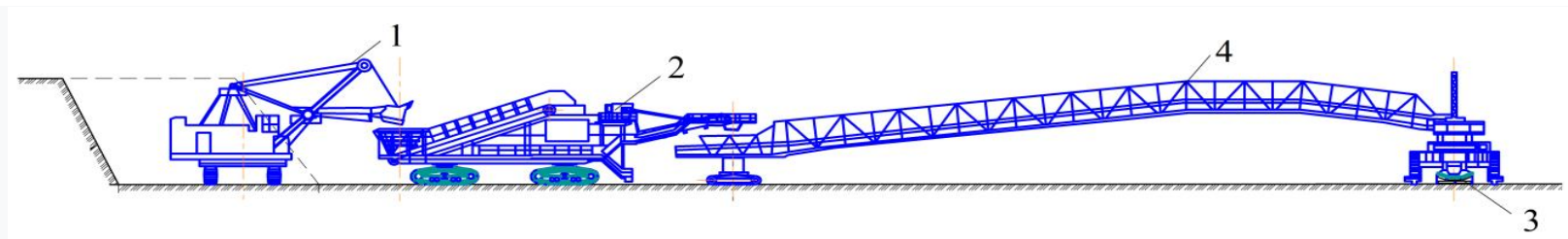

Figure 1: Schemes for the development of rocks using conveyor transport1 - excavator; 2 - mobile crushing plant; 3 - face belt conveyor; 4 - mobile conveyor-reloader;

\section{METHODOLOGY}

Cyclic flow technology at the overburden complex consists of the following technical links [2,8,12]:

- excavator (ЭКГ-15) - 3 units;

- a mobile crushing plant receives rock mass from an ЭКГ-15 excavator with its subsequent loading onto a downhole inter-step reloader with with performance of $\mathrm{Q}=$ 4000 t/h - 3 units;

- downhole bridge-type crusher, used as a connecting link between the mobile crusher and the face conveyor and transferring the crushed rock mass from the mobile crusher to the face belt conveyor with a working bench height of $15 \mathrm{~m}$ and with performance of $\mathrm{Q}=4000 \mathrm{t} / \mathrm{h}-3$ units;

- belt conveyor used to transport rock mass from a mobile crusher to a spreader with a total number of overburden belt conveyors 14;

- a spreader designed for dumping overburden into an internal dump with an unloading boom length of $60 \mathrm{~m}$, a total length of $110 \mathrm{~m}$ and with performance of $\mathrm{Q}=12100$ t/h - 1 unit.

The sequence of work in the central heating center is carried out as follows: the ЭКГ-15excavator loads the overburden into the bunker of the crushing plant, then the overburden from the bunker enters the plate conveyor,from there, through the hopper, it enters a two-roll crusher, which passes through itself the transported material with a size of $1100 \mathrm{~mm}$ at the exit up to $300 \mathrm{~mm}$. The overburden goes through the crusher's outlet chute to belt conveyor, which transports it to a mobile transfer loader.

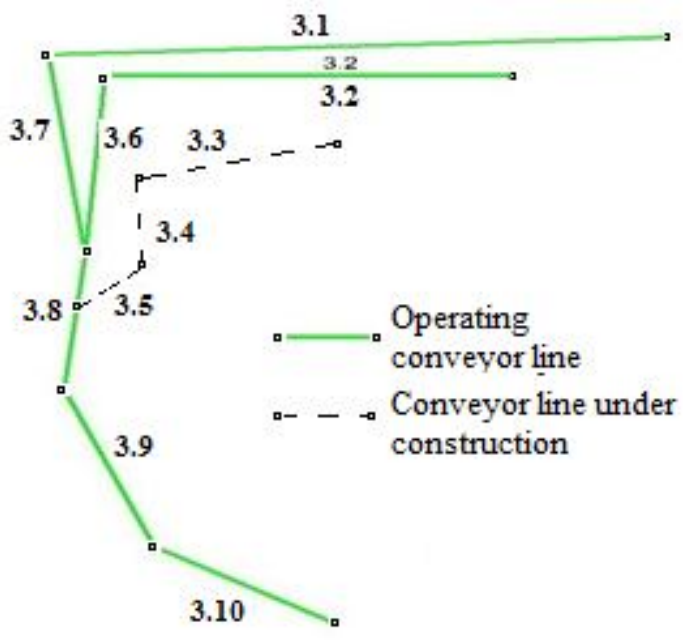

Figure 2: Layout of overburden conveyors
Further transportation of the rock mass is carried out by a main conveyor with a capacity of $12100 \mathrm{t} / \mathrm{h}$, followed by reloading onto a dump conveyor, from where the rock mass moves to a spreader, which forms internal dumps. Details of the technical parameters of the conveyors are given in table. 1.The layout of the constructed 1 and 2 lines and the 3 line under construction is shown in Fig. 1.

\section{Overburden transportation:}

\section{CFT of the 1-tier.}

A face conveyor № 3.1 pours overburden onto the transfer conveyor №3.7, which in turn transports the soil to the transfer onto the main conveyor № 3.8 (Fig. 2).

With the advancement of the work front, the transfer conveyor №3.7 is built uppreserving its initial bearing azimuth.

\section{CFT 2-tier.}

A face conveyor № 3.2 pours overburden onto the transfer conveyor № 3.6 and then onto the main conveyor № 3.8 . To ensure the advancement of the work front, the intermediate conveyor № 3.6 will be built up

\section{CFT 3-tier.}

A face conveyor № 3.3 horizon pours overburden onto the transfer conveyor № 3.4, which in turn transports the soil to the transfer conveyor № 3.5. Further, on the transfer conveyor, the soil is delivered to the dump conveyor № 3.8.

Ensuring the advancement of the work front is achieved by building up the transfer conveyor № 3.4.

The belt conveyors that are used at the Angren coal mine have structures of a stationary type, a semi-stationary type and a mobile structure with rails [5].

The head station and tail station of the conveyor, which has a semi-stationary type structure, are located on steel skis, the middle section is located on short steel sleepers, and hooks are laid on the side of the middle section for fastening the cable.

The head station and tail station of the conveyor, which has a mobile structure with rails, are located on steel skis, the middle section is located on long steel sleepers on which the rails are laid, and a loading carriage with a carriage with a cable drum and a dump carriage are equipped, on board the middle section are laid hooks for fastening the cable. A characteristic feature of the use of the central heating center is the flow of the entire technological chain, the stoppage or failure of the operation of individual links 
or devices, leads to the stoppage of all lines of the complex. To exclude such situations, the strictest control over the implementation of technical operation standards is introduced. Another way to anticipate emergencies is early diagnosis and anticipated malfunctions and repairs.

Table 1: The actual length of the conveyor lines of the overburden CFT of the Angren coal mine branch

\begin{tabular}{|c|c|c|c|c|c|c|}
\hline № & Conveyor & $\begin{array}{c}\text { Actual length } \\
(\mathbf{m})\end{array}$ & $\begin{array}{c}\text { Actual tilt } \\
\text { angle } \\
\text { (degree) }\end{array}$ & $\begin{array}{c}\text { Installation } \\
\text { horizon of the } \\
\text { drive station }\end{array}$ & $\begin{array}{c}\text { Take-up } \\
\text { station } \\
\text { installation } \\
\text { horizon }\end{array}$ & $\begin{array}{c}\text { Angle of } \\
\text { rotation } \\
\text { (degree) }\end{array}$ \\
\hline 1 & 3.1 & 960 & 0,20 & $+955 \mathrm{~m}$ & $+950 \mathrm{~m}$ & 79 \\
\hline 2 & 3.2 & 520 & 1 & $+926 \mathrm{~m}$ & $+915 \mathrm{~m}$ & 110 \\
\hline 3 & 3.6 & 354 & 1 & $+931 \mathrm{~m}$ & $+926 \mathrm{~m}$ & 173 \\
\hline 4 & 3.7 & 855 & 1 & $+933 \mathrm{~m}$ & $+955 \mathrm{~m}$ & 169 \\
\hline 5 & 3.8 & 806,5 & 0,74 & $+941 \mathrm{~m}$ & $+931 \mathrm{~m}$ & - \\
\hline 6 & 3.9 & 631 & 0,47 & $+936 \mathrm{~m}$ & $+941 \mathrm{~m}$ & 159 \\
\hline 7 & 3.10 & 350 & 0 & $+936 \mathrm{~m}$ & $+936 \mathrm{~m}$ & 163 \\
\hline & Total & $\mathbf{4 4 7 6 , 5}$ & & & & \\
\hline
\end{tabular}

The control system of the CFT complex operates identically to similar systems and includes an automated workstation for the user. All links of the complex are connected into a single network, the process of which is displayed on the computer monitor. From the central control center, the user visually monitors the work of the central heating center in real time.

The problems of improving the cyclical-flow technology in open-pit mining are due to the mining conditions of open pits. These conditions determine the need to develop new technological and technical solutions for the adaptation of the CFT, taking into account the specific mining and geological conditions of the open pit.

World practice in open pit mining shows that in large open-pit mines the use of various types of CFT is becoming more and more widespread. Taking into account the extensive experience of using this technology in various deposits, the economy in the transportation of rock mass and energy consumption, saving human resources, it is not difficult to foresee that the future development of open pit mining is behind this technology.

Let us consider the technological scheme for the development of rocks by the end-face arrangement of mobile crushing, reloading and conveyor complexes (MCRCC) using a single-bucket excavator with a block length $\mathrm{L}=500 \mathrm{~m}$ and the duration of the complex operation for 1 year (Fig. 3) [3,11].

The minimum width of the working platform should be equal to one entry of the excavator, taking into account the overall dimensions of the crushing plant.

Table 2:List of technical parameters of stripping belt conveyors of the central heating center of the Angren coal mine

\begin{tabular}{|l|c|c|c|c|c|c|c|c|c|}
\hline & & & & & & \\
Conveyor \\
classification
\end{tabular}




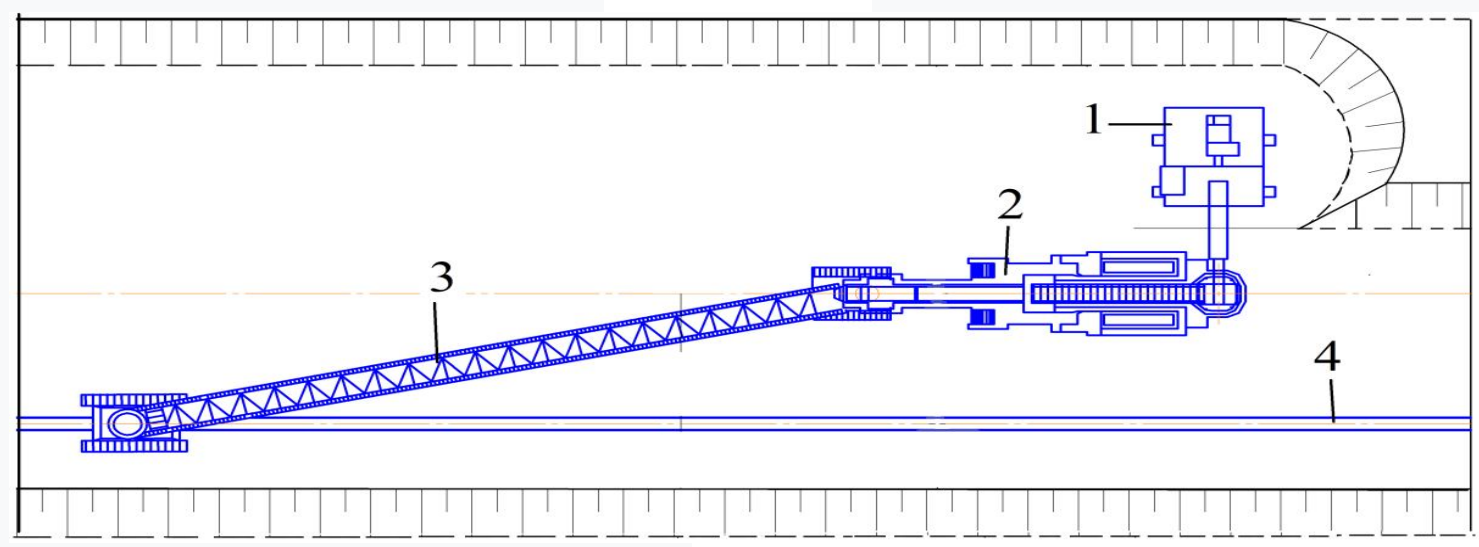

Figure 3:Technological scheme for the development of rocks with the end location of MCRCC with an increased width of the working platform: 1 - excavator; 2 - mobile crushing plant; 3 - mobile conveyor loader; 4 - face conveyor

\section{METHODOLOGY FOR DETERMINING OPERATION TIME AND PRODUCTIVITY OF THE MCRCC COMPLEX}

The width of the strip at the same time taken out is determined by the formula $[6,11]$ :

$$
\mathrm{B}_{n}=R_{\mathrm{d}}+R_{u}+l_{u c}+l_{l c}-C_{1}, \mathrm{~m},
$$

$R_{\mathrm{d}}$ - excavator digging radius at the standing level, m; $R_{u}$ - excavator unloading radius, $\mathrm{m}$;

$l_{u c}$ - departure of the discharge cantilever conveyor of the MCP, m;

$l_{\mathrm{lc}}$ - effective length of the loading conveyor, $\mathrm{m}$;

$C_{1}$, - the minimum safe distance from the edge of the camber to the conveyor line, $\mathrm{m}$.

Let us determine the annual productivity of the MCRCC complex according to this technological scheme (Fig.3).

The total annual productivity of the MCRCC system depends on mining-geological, mining-technical, technological and organizational factors and is determined taking into account the advancement of the mining front $[6,12,13,14]$ :

$$
Q_{c}=U_{f} L_{b} h, \mathrm{~m}^{3} / \text { year, }
$$

$U_{f}$ - length of advance of the front of mining operations, m; $L_{b}$ - block length, m $\left(L_{b}=500 \mathrm{~m}\right) ; \mathrm{h}$ - bench height, $\mathrm{m}$.

In the technological scheme of the development of rocks by the end position of the MCP with the use of a singlebucket excavator and conveyor transport, it takes a long time to move the face conveyor along the front. In this regard, when determining the annual productivity of the complex, the time of moving the face conveyor together with the development time of the entire length of the block is taken into account.

The working time of the complex during the development of one block (cycle) is

$$
T_{C Y C L E}^{1}=\frac{V_{B L O K}}{Q_{\text {oper }}^{h} K_{\mathrm{P}}}=\frac{\mathrm{B}_{W} L_{B} \mathrm{H}_{L}}{Q_{\text {O.P. }} K_{\mathrm{P}}},
$$

where $Q_{\text {oper }}^{h}$ - is the operational productivity of the complex, $\mathrm{m}^{3} / \mathrm{h} ; K_{\mathrm{P}^{-}}$coefficient of productivity reduction, taking intoaccount the shutdown of the complex, technological and organizational factors $\left(K_{\mathrm{P}}=0.85-0.95\right)$; $V_{B L O K}$ - the volume of the processed block, $\mathrm{m}^{3} ; \mathrm{B}_{\mathrm{W}}$ excavation trench width, $\mathrm{m} ; L_{B}$ - block length, $\mathrm{m} ; \mathrm{H}_{\mathrm{L}}$ ledge height, $\mathrm{m}$.

The time of movement of the downhole conveyor is determined by the formula [8]

$$
\mathrm{T}_{D . \mathrm{C} . \mathrm{M} .}=t_{p}+\frac{\mathrm{B}_{W} L_{d} K_{i}}{K_{S}^{t} P_{T}}+t_{f},
$$

where $t_{p}$ - is the time for preliminary and auxiliary operations when moving the conveyor stand $\left(t_{p}=3 \mathrm{~h}\right.$ according to [8]);

$L_{d}$ - the length of the stav downhole conveyor, m;

$K_{i}$ - coefficient taking into account the influence of production conditions on the implementation of the movement process ( $K_{i}=1,2$ according to [8]);

$K_{s}^{t}$ - coefficient of use of the tournode doser during the shift $\left(K_{s}^{t}=0.56\right.$ according to [3]);

$t_{f}$ - time for final operations when moving the conveyor bed $\left(t_{f}=4\right.$ hours according to [8]); $P_{T} P_{T}$ - technical productivity of the tournode doser

$$
P_{T}=v_{T}+B_{T}, \mathrm{~m}^{2} / \mathrm{h}
$$

where $v_{T}$ - operating speed of a tournode doser, $\mathrm{m} / \mathrm{h}$; $B_{T}$ - step width of the stroke of the tournode doser, $\mathrm{m}$

The annual operating time of the complex, taking into account the working time of the excavator, is determined by the formula:

$$
\mathrm{T}_{\mathrm{A}}=\mathrm{T}_{\mathrm{SH}} \mathrm{n}_{\mathrm{SH}} \mathrm{N}_{\mathrm{W}} \mathrm{K}_{\mathrm{U}}
$$

where $\mathrm{T}_{\mathrm{SH}}$ - the duration of the shift, h;

$\mathrm{n}_{\mathrm{SH}}$ - the number of shifts per day; 
$\mathrm{N}_{\mathrm{W}^{-}}$the number of working days of the excavator per year;

$\mathrm{K}_{\mathrm{U}^{-}}$utilization factor of the complex change time (is $\mathrm{K}_{\mathrm{U}}=$ 0,73-0,85).

The number of cycles performed in the developed blocks of the complex per year is determined by the formula:

$$
\mathrm{N}_{\text {CYCLE }}^{1}=\frac{\mathrm{T}_{\mathrm{A}}}{\mathrm{T}_{\text {CYCLE }}^{1}+\mathrm{T}_{\text {m.d.k }}}
$$

The annual productivity of the complex is determined by the formula:

$\mathrm{Q}_{\text {COM }}^{\mathrm{A}}=V_{B L O K} \cdot \mathrm{N}_{\text {CYCLE }}^{1}=\mathrm{B}_{W} L_{B} \mathrm{H}_{L} \cdot \mathrm{N}_{\text {CYCLE }}^{1}, \mathrm{~m}^{3} /$ year

\section{RESULTS}

In the table 3 shows the results of calculations of the annual productivity of the MCRCC complex at different block lengths according to the $1 \mathrm{st}$ option of the technological scheme.

According to the results of calculations, according to table. 3 , the dependence of the annual productivity of the MCRCC complex on the block length was obtained, which is shown in Fig. 4.

Table 3:Calculation results of the MCRCC complex during the development of benches according to the technological scheme for the development of rocks with the end face of the equipment using a bucket excavator and conveyor transport

\begin{tabular}{|c|c|c|c|c|c|c|c|c|}
\hline$Q_{\text {com }}^{A}, \mathrm{~m}^{3} / \mathrm{y}$ & $Q_{\text {oper }}^{h}, \mathrm{~m}^{3} / \mathrm{h}$ & $\begin{array}{l}V_{\text {BLOCK }}, \\
\mathrm{m}^{3}\end{array}$ & $\begin{array}{l}\boldsymbol{T}_{\text {CYCLE }}, \\
\mathrm{h}\end{array}$ & $\begin{array}{l}\boldsymbol{L}_{\mathrm{BLOCK}}, \\
\mathrm{m}\end{array}$ & $\begin{array}{l}\mathrm{T}_{\text {D.C.M. }} \text {, } \\
\mathrm{h}\end{array}$ & $\boldsymbol{T}_{\mathrm{A}}, \mathrm{h}$ & $\mathbf{N}_{\text {CYCLE }}^{1}$ & $\begin{array}{l}\Delta \mathrm{t}_{\text {п.Z.к. }}, \\
\%\end{array}$ \\
\hline 4767252,6 & 1478 & 53400 & 40,14 & 200 & 19,71 & 5344 & 89,3 & 0,099 \\
\hline 4960630,4 & 1478 & 80100 & 60,21 & 300 & 26,07 & 5344 & 61,9 & 0,087 \\
\hline 5063324,2 & 1478 & 106800 & 80,28 & 400 & 32,43 & 5344 & 47,4 & 0,081 \\
\hline 5127007,1 & 1478 & 133500 & 100,4 & 500 & 38,79 & 5344 & 38,4 & 0,078 \\
\hline 5170359,8 & 1478 & 160200 & 120,4 & 600 & 45,14 & 5344 & 32,3 & 0,075 \\
\hline 5201777,6 & 1478 & 186900 & 140,5 & 700 & 51,5 & 5344 & 27,8 & 0,074 \\
\hline 5225592,7 & 1478 & 213600 & 160,6 & 800 & 57,86 & 5344 & 24,5 & 0,072 \\
\hline 5244266,9 & 1478 & 240300 & 180,6 & 900 & 64,21 & 5344 & 21,8 & 0,071 \\
\hline 5259302,5 & 1478 & 267000 & 200,7 & 1000 & 70,57 & 5344 & 19,7 & 0,071 \\
\hline 5271668,7 & 1478 & 293700 & 220,8 & 1100 & 76,93 & 5344 & 17,9 & 0,070 \\
\hline 5282018,4 & 1478 & 320400 & 240,8 & 1200 & 83,29 & 5344 & 16,5 & 0,069 \\
\hline 5290807,6 & 1478 & 347100 & 260,9 & 1300 & 89,64 & 5344 & 15,2 & 0,069 \\
\hline 5298364,6 & 1478 & 373800 & 281 & 1400 & 96 & 5344 & 14,2 & 0,069 \\
\hline 5304931,4 & 1478 & 400500 & 301,1 & 1500 & 102,4 & 5344 & 13,2 & 0,068 \\
\hline 5310690,7 & 1478 & 427200 & 321,1 & 1600 & 108,7 & 5344 & 12,4 & 0,068 \\
\hline 5315782,9 & 1478 & 453900 & 341,2 & 1700 & 115,1 & 5344 & 11,7 & 0,068 \\
\hline 5320317,5 & 1478 & 480600 & 361,3 & 1800 & 121,4 & 5344 & 11,1 & 0,067 \\
\hline
\end{tabular}

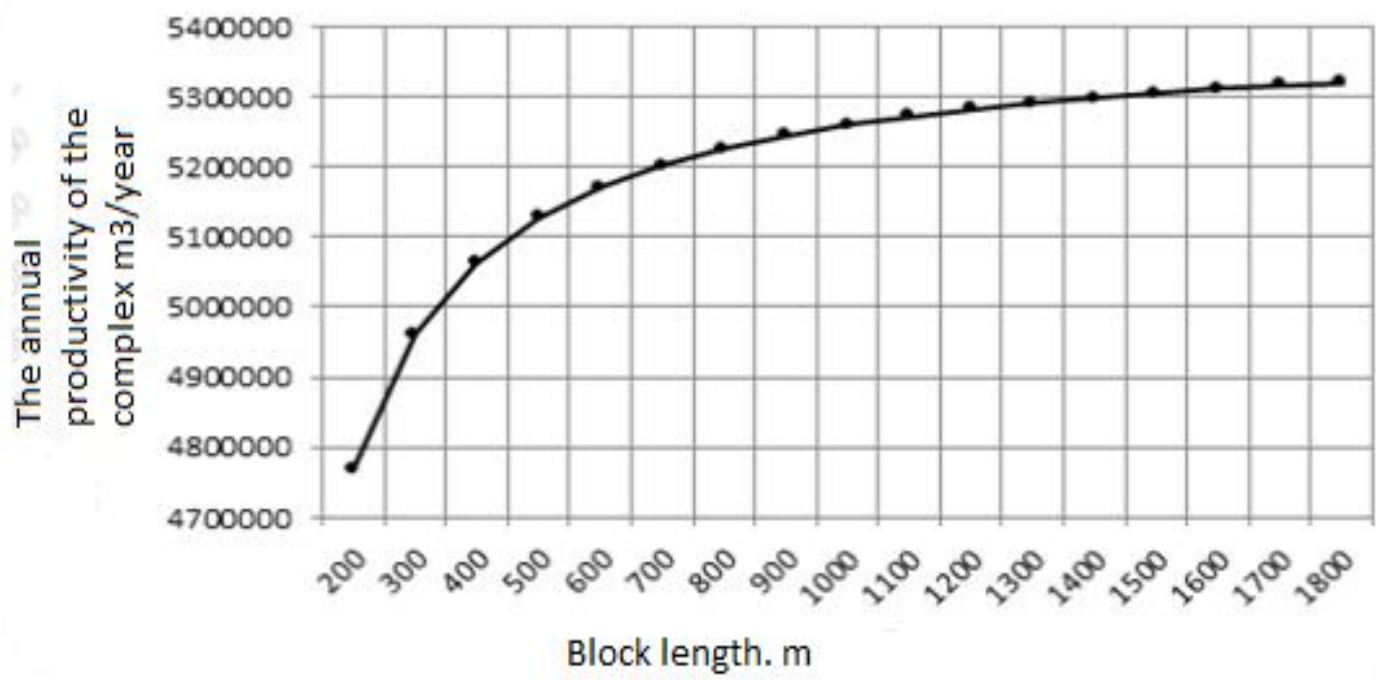

Figure4. Dependence of the annual productivity of the MCRCC complex on the length of the block and a comparison of three variants of technological schemes 


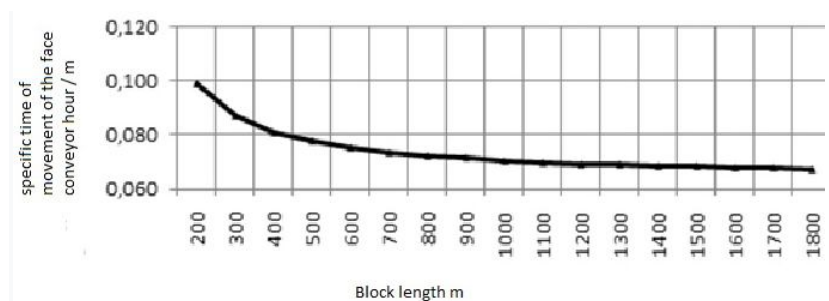

Figure 5. Dependence of the change in the specific time of movement of the face conveyor on the length of the block.

\section{CONCLUSION}

The results obtained show that the productivity of the MCRCC complex increases with increasing block length. This is due to a decrease in the number of cycles during the period of operation throughout the year.

Studies have also found that the productivity of the MCRCC complex increases with a decrease in the specific time for moving the face conveyor per working cycle (Fig. 5).

The novelty of this technological scheme is the movement of the complex following the movement of the excavator in the face and thereby ensuring the flexibility and mobility of the entire mining and transport system. In combination with continuously operating conveyors, the mobile crushing complex makes it possible to abandon the alternative excavator-motor transport scheme and the fleet of heavy-duty dump trucks. In addition to reducing mining costs, the development technology based on the new fully mobile crushing system also provides significant reductions in exhaust gas emissions into the atmosphere.

Thus, the recommended process flow diagram of the overburden mining center with the use of mobile crushingtransfer-conveyor complexes ensures the dynamic development of mining operations along the front and depth with high technical and economic indicators of open pit mining.

\section{REFERENCES}

1. Nasirov U.F, Zairov Sh.Sh., AnnakulovT.J. Application of schemes of cyclical-flow technology with mobile and mobile crushing and reloading complexes in open pit mining, Scientific-technical and production journal "'Mining journal of Uzbekistan", Vol.2, pp.36-39, June, 2019.

2. Annakulov T.J. Improvement of cyclic-flow technology development overburden cut Angren with mobile complexes, European Applied Sciences, ORT Publishing. -Stuttgart, Germany, Vol.6, pp. 5860, 2015.

3. Annakulov T.J. Intensification of cyclical-flow technology with the use of mobile complexes in coal deposits, Ph.D. dissertation, Geotechnology (open, underground, construction), Navoiy, Uzb, 2019.

4. Zairov Sh.Sh., Annakulov T.J., Kuvondikov O.A., Sharipov L.O. Calculation of technological parameters of equipment sets for mobile crushing, reloading and conveyor complexes, Scientifictechnical and production journal "Mining journal of Uzbekistan", Vol.3, pp.29-34, September, 2019.

5. Usmanov N.S., Tsoy I.V., Irkabaev U.U., Nasriddinov I.Kh., Annakulov T.J. The experience of introducing cyclic-flow technology at the overburden complex of the Angren coal mine, Scientific-technical and production journal "Mining journal of Uzbekistan", Vol.1, pp.82-86, June, 2019.

6. Rjevskiy V.V. Open pit mining. Technology and complex mechanization, Textbook. - M.: ed. "LENAND", 2015. - 552 p.

7. AnnakulovT.J., ZairovSh.Sh., Kuvandikov O.A. Justification, selection and calculation of technological parameters of equipment kits of mobile crushing-reloading-conveyor complexes, International Journal of Advanced Research in Science, Engineering and Technology.- India: National Institute of Science Communication and Information Resources, Vol.6. - Issue 2. - pp. 80728079, Fevruiary, 2019.

8. Annakulov T.J. Development of technological schemes for open-pit mining of fields using mobile complexes, Materials of the XXIV International Scientific and Practical Conference on the topic: "Innovation-2019". - Tashkent: Tashkent State Technical University, 2019, pp. 192-194.

9. Mohammad Reza Tavakoli Mohammadi, Seyed Ahmad Hashemi, Farhad Moosakazemi. Review of the in-pit crushing and conveying (IPCC) system and its case study in copperindustry,https://www.researchgate.net/publicat ion/270888181.

10. Annakulov T.J., Shamsiyev R.N., Kuvondikov O.A. Mathematical modeling of determining the productivity of mobile complexes in exercise of inclined connecting accessories, International Journal of Emerging Trends in Engineering Research, Vol. 8. №6, pp.2695-2701, June, 2020.doi.org/10.30534/ijeter/2020/77862020.

11. Annakulov T.J.Development of technological schemes for open-pit mining of deposits using mobile crushing-reloading-conveyor complexes, E3S Web of Conferences 201, 01010 (2020). Ukrainian School of Mining Engineering2020.https://doi.org/10.1051/e3sconf/202020101010.

12. Faul A.A. Determination of parameters and indicators of opencast mining of deposits of nonmetallic building materials using mobile crushing complexes, Diss. ...cand. tech. sciences. - S.Pb., 2012. 193 p.

13. Mirsaidov G.M., Annakulov T.J., Raimberdiev S.U., Abdullaev A.A. Determination of the optimal width of the excavator approach when using mobile systems in the conditions of the development of overburden benches of the Angrensky open pit, Materials of the international scientific and practical conference "LXI international scientific readings (in memory of A.N.Kolmogorov): Collection of articles. Moscow: December 16, 2019, pp. 67-73.

14. Nasirov U.F., Zairov Sh.Sh. Annakulov T.J. Methodology for calculating technological parameters of sets of equipment for mobile 
Annakulov Tulkin et al., International Journal of Emerging Trends in Engineering Research, 9(4), April 2021, 383 - 389

crushing-transfer-conveyor complexes, Proceedings of the international scientific and technical conference "Rational use of mineral and technogenic raw materials in industry 4.0". - Almaty, 2019. pp. 230234. 